\title{
Double origin of the racer goby (Babka gymnotrachelus) in Poland revealed with mitochondrial marker. Possible implications for the species alien/native status
}

\author{
Michał GRABOWSKI, ${ }^{1 *}$ Kamil HUPAŁO,${ }^{1}$ Aneta BYLAK,,${ }^{2}$ Krzysztof KUKUŁA, ${ }^{2}$ Joanna GRABOWSKA ${ }^{3}$ \\ ${ }^{1}$ Department of Invertebrate Zoology and Hydrobiology, University of Lodz, Banacha 12/16, 90-237 Lodz; ${ }^{2}$ Department of \\ Environmental Biology, University of Rzeszow, Zelwerowicza 4, 35-601 Rzeszow; ${ }^{3}$ Department of Ecology and Vertebrate Zoology, \\ University of Lodz, Banacha 12/16, 90-237 Lodz, Poland \\ *Corresponding author: michalg@biol.uni.lodz.pl
}

\begin{abstract}
In mid-1990s racer goby (Babka gymnotrachelus) penetrated to the Vistula and Western Bug rivers in Poland through the canal connecting the Baltic and the Black Sea basins, namely the Vistula and Dnieper drainages. In early 2000s, the species was reported from Polish section of the Strwiaż River that is an affluent of the Dniester River that drains to the Black Sea basin. According to the Polish legislation, the racer goby has been enlisted as an alien invasive species that may pose threat to local biota. Our analysis of the $m t D N A$ cytochrome b diversity revealed that the Vistula/Western Bug and Strwiaz populations are different genetic units. First one originated from the Dnieper River, while the second derives from the Dniester River. According to the results of mismatch analysis, both are in the stage of demographic and spatial expansion. The haplotype frequencies in population from the Vistula/Western Bug differ significantly from those in the source population in Dnieper, suggesting founder effect, possibly due to human-mediated introduction of low number of individuals. On the other side, the population in Strwiaż does not differ in structure from the one in Dniester, providing a hint towards spontaneous range expansion. Interpretation of our results in light of historical data lead to the conclusion that presence of racer goby in Strwiaż was probably overlooked in previous, spatially limited, studies. Thus, in Strwiaż the species should not be treated as alien, contrary to its status in the Vistula drainage. This double origin of racer goby populations in Poland creates a peculiar situation for national legislation procedures as one population is alien and invasive, while the other one is not. In light of our findings, the population from Strwiaż should be recognised as a special case. Steps should be undertaken to raise public awareness to prevent translocation of the gobies between the rivers to prevent deterioration of the evolutionarily isolated genetic pools of the Dnieper and of the Dniester basins. Our results illustrate the need for case studies upon genetic population structure, following appearance of new species in previously unoccupied water bodies, even on local scale.
\end{abstract}

Key words: Alien aquatic species; population genetic structure; legal status; Ponto-Caspian invaders.

Received: May 2015. Accepted: August 2015.

\section{INTRODUCTION}

The territory of Poland is shared largely between the Vistula and Oder river systems and $99.7 \%$ of the country area belongs to the Baltic Sea drainage basin. Only $0.1 \%$ of the area, in south-western Poland is drained to the North Sea via the Elbe river system. The remaining $0.2 \%$ of the area in south-eastern Poland belongs to the Black Sea basin, draining largely to the Strwiąż River, which is a tributary of the upper Dniester. Due to the artificial canals connecting the main rivers belonging to the Baltic basin and further joining them to the basin of the Black Sea and of the North Sea, the hydrographic network in Poland is an important stepping stone area for numerous alien and invasive aquatic species migrating from the Ponto-Caspian region to Western Europe. Three main routes of their expansion have been defined and named by Bij de Vaate et al., (2002) as the northern, central and southern migration corridor. Particularly the two latter routes have been used by five species of Ponto-Caspian gobies - the most expansive alien fish from that region (Copp et al., 2005). The racer goby, Babka gymnotrachelus (Kessler, 1857) (syn. Neogobius gymnotrachelus (Kessler, 1857)), colonised the middle and the upper parts of Danube (Roche et al., 2013), from where it migrated to Rhine via the Rhine-Main-Danube Canal (Borcherding et al., 2011). Already in mid-1990s the species was found in the Vistula river system - first in the Western Bug and soon after, in 2000, in the Vistula itself (Danilkiewicz, 1996; Kostrzewa and Grabowski, 2001). It was the first Ponto-Caspian gobiid recorded in the Baltic stretch of the central corridor (Kostrzewa and Grabowski, 2003; Grabowska et al., 2008). Apparently, the species reached Poland through the Pripyat-Bug canal that connects the Black and Baltic basins, namely the Dnieper and Vistula drainages, since the end of the $18^{\text {th }}$ century. Such invasion route was initially concluded from the first record locality of the racer goby in the Western Bug and the known his- 
tory of its previous expansion in Ukraine and Belarus (Danilkiewicz, 1996; Grabowska et al., 2008, Semenchenko et al., 2011). Ohayon and Stepien (2007) revealed that the invasive population from the Vistula River is genetically identical to the native one inhabiting the Dnieper River, proving the Pripyat-Bug canal as the invasion route of racer goby to the Baltic basin. Besides, the authors reported that the populations inhabiting the Danube, Dniester and Dnieper (i.e. the species native area) are genetically distinct units.

Soon after its first record in the Vistula river system, in 2003, two individuals of racer goby were found in the Polish section of the Strwiąż River belonging to the Black Sea basin (Amirowicz and Kukuła, 2005). Already in 2009, the racer goby dominated the local fish assemblage with a density of 3.4 ind $\mathrm{m}^{2}$ and since then has remained very abundant (Kukuła and Bylak, 2010, 2013). The earlier ichthyological surveys did not reveal presence of that species in the Polish section of Strwiąż (Rolik, 1967, 1971), whereas fish fauna in the Ukrainian part of this river has never been surveyed. The racer goby is reported as native to Dniester and its tributaries, such as: Zbruch, Zwanchik, Smotrych, Reut and Bystrica (Smirnov, 1986; Khudyi, 2002; Romanescu, 2010; Manilo, 2014). Thus, the Dniester River would seem as the most obvious donor area. However, the origin of the population in Strwiąż cannot be judged with certainty. The upper Strwiąż in Poland neighbours with the Vistula drainage system. Although the distance between Strwiąż and San, a major tributary of Vistula, is ca. $10 \mathrm{~km}$ there are no natural or artificial connections between the two rivers. So far there are no reports on presence of racer goby in the San River. Yet, its introduction from the Vistula basin, e.g., as live bait, cannot be excluded. Knowing that the Dnieper population (being the source for the invasion of Vistula) is distinct in genetic terms from the one in the Dniester basin, its translocation to the latter one could be treated as pollution of the local genetic pool of the racer goby. Furthermore, if indeed the population in Strwiąż is of the Dniester origin then it cannot be unequivocally defined as alien unless proven as expanded/introduced due to human activity. Then, if this population is not alien (contrary to the one in Vistula and Bug rivers), it would create a very peculiar situation and need for redefining the legal status of the species in Poland. At present, the racer goby has been enlisted as an alien invasive species posing threat to local biota (Rozporządzenie Ministra, 2011).

Thus, our aim was to clarify the identity, origin and genetic population structure of the racer goby population from the Strwiąż River in comparison with the invasive population from the Vistula and Western Bug based on a sequenced portion of the mitochondrial cytochrome $b$ gene. The results were compared to the already published data upon genetic composition of the native populations from the Dniester and Dnieper. Finally, we discussed our results with literature on the distribution of the racer goby in the Dniester basin and presented implications of our findings for the species invasive/native status of the populations of racer goby in Poland.

\section{METHODS}

Individuals of racer goby were collected in 2013 from several localities along Western Bug, Vistula and from the Strwiąż River (Fig. 1, Tab. 1). Samples of fins or muscle tissue were fixed in situ in 96\% ethanol and then stored at room temperature. Each sample was homogenized in a $1.5 \mathrm{~mL}$ tube containing $200 \mathrm{~mL}$ of Queen's lysis buffer (Seutin et al., 1991) and incubated overnight at $55^{\circ} \mathrm{C}$ with $5 \mathrm{~mL}$ of proteinase $\mathrm{K}(20$ $\mathrm{mg} / \mathrm{mL}$ ). The total DNA was then extracted based on a standard phenol-chloroform method as described by Hillis et al. (1996). Air-dried DNA pellets were re-suspended in $100 \mathrm{~mL}$ of TE. The mitochondrial cytochrome $\mathrm{b}$ gene was amplified with the polymerase chain reaction (PCR) in $20 \mu \mathrm{L}$ reactions containing $2 \mu \mathrm{L}$ (c. $100 \mathrm{ng}$ ) of template DNA and $18 \mu \mathrm{L}$ of mix containing $10 \mu \mathrm{M}$ Tris$\mathrm{HCl}$ buffer $\mathrm{pH} 8,400 \mathrm{nM}$ of each primer, $200 \mu \mathrm{M}$ of each dNTP and $1 / 2$ units of Taq polymerase. Primers were AJG15 (Akihito et al., 2000) and H15343g (Ohayon and Stepien, 2007). A negative control containing no template DNA was used in each run. PCR reactions comprised 35 cycles of $45 \mathrm{~s}$ at $94^{\circ} \mathrm{C}$ (denaturation), $30 \mathrm{~s}$ at $52^{\circ} \mathrm{C} \mathrm{(annealing)} \mathrm{and} 60 \mathrm{~s}$ at $72^{\circ} \mathrm{C}$ (extension), followed by a final extension step for $3 \mathrm{~min}$. PCR prod-

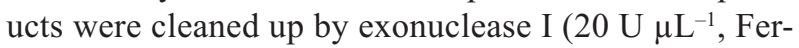
mentas, Vilnius, Lithuania) and alkaline phosphatase FastAP (1 U $\mu \mathrm{L}^{-1}$, Fermentas) treatment according to the manufacturer's guidelines. Sequencing of the PCR products was performed using BigDye terminator technology by Macrogen Inc. (Seoul, Korea) using the same primers as at the amplification stage. Sequences were edited and aligned using Bioedit, ver. 7.2.4 (Hall, 1999; http://www.mbio.ncsu.edu/BioEdit/bioedit.html) with ClustalW plug-in. Haplotypes were identified by eye.

To test for the genetic dissimilarities between populations sampled at different localities along the Dnieper-Vistula and Dniester-Strwiąż routes, we used the $\mathrm{F}_{\mathrm{st}}$ estimator as well as the exact test of population differentiation $\left(\chi^{2}\right.$ contingency test comparisons) implemented in Arlequin 3.5.1.3 (Excoffier and Lischer, 2010). Further, two models of expansion, demographic and spatial, were examined in Arlequin, using mismatch distribution analysis (Slatkin and Hudson, 1991; Rogers and Harpending, 1992) with 1000 replicates in case of both, the Vistula/Western Bug and Strwiąż populations. Haplotype frequencies for the native localities (Dnieper, Dniester) were derived from the paper by Ohayon and Stepien (2007). 


\section{RESULTS}

A 439 bp long portion of cytochrome gene was sequenced from 82 individuals of racer goby from Polish waters (Tab. 1). This number included 22 individuals from two sites along the Vistula River (Baltic basin) and 17 individuals from two sites along the Western Bug River, the Vistula's main tributary, connected by the artificial channel to the Dnieper system (Black Sea basin) (Fig. 1). The remaining 43 individuals came from the Strwiąż River - a tributary of the upper Dniester River (Black Sea basin) (Fig. 1). The dataset contained no length mutations. In result we found two haplotypes in the Vistula and in the Western Bug River (reference haplotypes $\mathrm{G}$ and $\mathrm{H}$, from earlier work of
Ohayon and Stepien (2007), of which the haplotype H dominated with frequency from 0.88 to 1 . Two different haplotypes were found in the Strwiąż River (reference haplotypes A and E, from Ohayon and Stepien, 2007), of which the haplotype A was dominant with the frequency of 0.98. Completely different haplotype compositions stand for recognising the Vistula/Western Bug and Strwiąż populations as genetically distinct units, each with its own evolutionary history. On the other side, qualitative compositions of haplotype assemblages in the Vistula/ Western Bug and Strwiąż indicate that they originated from the Dnieper and Dniester, respectively. Both tests for the genetic dissimilarities between populations show significant differences in genetic structure between the invasive population in the

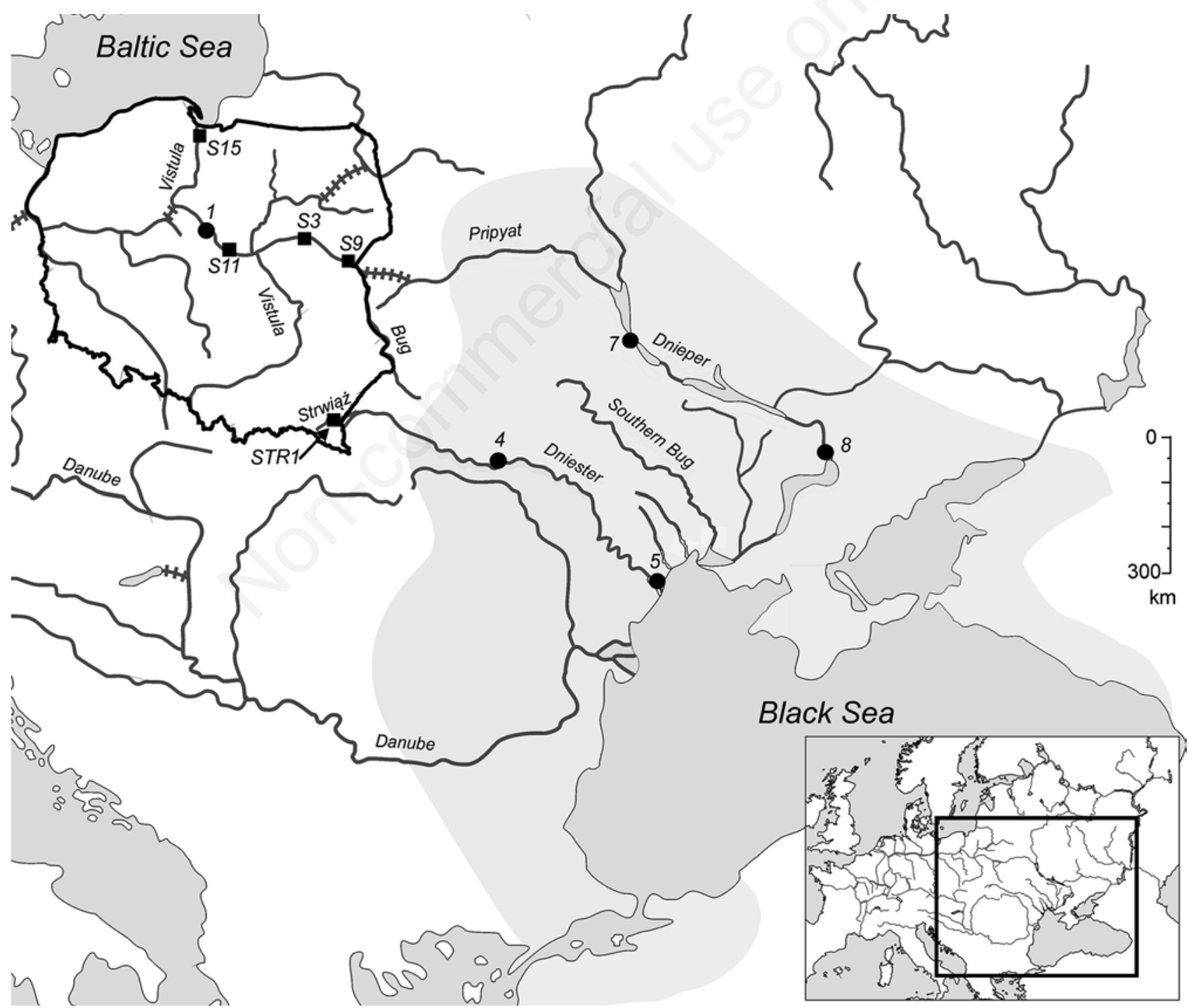

Fig. 1. Map indicating locations of sampling sites corresponding to Tab. 1. Shading indicates native range of the racer goby (Babka gymnotrachelus). Squares represent sampling sites from this study; dots represent sampling sites from other studies; grey ladder lines represent artificial canals; thick black line indicates the borders of Poland. 
Vistula/Western Bug and the native population in middle Dnieper (Tab. 2). It results from the fact that, although the haplotype assemblage $(\mathrm{H}, \mathrm{G})$ found in Vistula/Western Bug is identical to those in the middle Dnieper in qualitative terms, it displays somewhat reversed frequency of particular haplotypes (Tab. 1). On the other hand, no differentiation was detected in pair-wise comparisons between sites along the Vistula and Western Bug. Both, the low $F_{\text {st }}$ values and results of the exact test of differentiation do not show any difference in genetic structure between the population in Strwiąż and that in the middle Dniester; some level of differentiation may be observed between the Strwiąż population and population from the Dniester Estuary (Tab. 2). The haplotype assemblage (A, E) in Strwiąz, is a subsample of that found in the racer goby native region - the middle Dniester (A, B, E) and the Dniester Estuary (A, F) (Tab. 1).

Mismatch analysis and a neutrality test performed for both, the Strwiąż and Vistula/Western Bug, populations clearly indicate an episode of recent expansion in both demographic and spatial terms (Fig. 2).

\section{DISCUSSION}

Our results clearly indicate presence of two genetically distinct populations of racer goby (Babka gymnotrachelus) in Polish inland waters: one inhabiting the Vistula and Western Bug rivers, and the other one occurring in the Strwiąż River. Comparisons of haplotype assemblages in the above mentioned rivers with those in the native, Ponto-Caspian, range of the species strongly suggest that the two populations have very different origins.

In case of the Vistula River, based on one sample from the middle Vistula, Ohayon and Stepien (2007) concluded that the racer goby colonised the river from Dnieper, through the artificial Pripyat-Bug canal. Our samples were collected six years later all along the Western Bug River, from the entrance of the Pripyat-Bug canal to its confluence with the Vistula and from there down to Vistula estuary. Even such extended dataset confirms the Dnieper River as a sole source for the racer goby invasion in the Vistula River system without any signs of other introduction events, e.g. in the Vistula mouth. River mouths are known as invasion gateways, due to their transitional salinity regimes and presence of ports where ships discharge their ballast waters (Panov et al., 2009). For example, Vistula mouth served as an invasion gateway for the Ponto-Caspian round goby (Neogobius melanostomus (Pallas 1814)) (Grabowska et al., 2010). In case of the racer goby, it seems that the species, from its first finding in the middle Vistula in 2000, has colonised the river down to the mouth (more than $300 \mathrm{~km}$ ) in less than a decade. Such expansive stage of this population is supported by the results of the mismatch analysis and absence of differences in population genetic structure between localities along the river (Tab. 2).

Interesting is, though, the observed differentiation between the Vistula/Western Bug populations and the native one in the middle Dnieper. Plausibly, it results from the very different haplotype $H$ frequency, $0.88-1.00$ versus 0.20 , respectively. It may be interpreted as a sign of founder effect. Semenchenko et al. (2011) noticed that appearance of racer goby (and also several other alien fishes) in middle Pripyat and in Western Bug, coincided with the increased ship traffic in early 1990s. Thus, the introduction of racer goby to the middle Pripyat and, in consequence, to the Western Bug River could be a result

Tab. 1. Racer goby (Babka gymnotrachelus), sampling locations (location numbers in parentheses correspond to Fig. 1) and mtDNA cytochrome $b$ gene haplotype frequencies.

\begin{tabular}{|c|c|c|c|c|}
\hline Sampling site & Sampling date & Number & $\begin{array}{l}\text { Haplotype } \\
\text { of individuals }\end{array}$ & $\begin{array}{l}\text { Reference } \\
\text { frequencies }\end{array}$ \\
\hline $\begin{array}{l}\text { Western Bug } \\
\text { Wojtkowice (S3) } \\
\text { Białobrzegi (S9) }\end{array}$ & $\begin{array}{l}\text { VII } 2011 \\
\text { VII } 2011\end{array}$ & $\begin{array}{c}17 \\
8 \\
9\end{array}$ & $\begin{array}{l}\mathrm{G}(0.12), \mathrm{H}(0.88) \\
\mathrm{G}(0.11), \mathrm{H}(0.89)\end{array}$ & $\begin{array}{l}\text { This study } \\
\text { This study }\end{array}$ \\
\hline $\begin{array}{l}\text { Vistula } \\
\text { Włocławek (S11) } \\
\text { Kiezmark (S15) } \\
\text { Toruń (1) }\end{array}$ & $\begin{array}{l}\text { VII } 2011 \\
\text { VII } 2011 \\
2006\end{array}$ & $\begin{array}{c}34 \\
17 \\
5 \\
12\end{array}$ & $\begin{array}{c}\mathrm{G}(0.06), \mathrm{H}(0.94) \\
\mathrm{H}(1.00) \\
\mathrm{G}(0.08), \mathrm{H}(0.83), \mathrm{I}(0.08)\end{array}$ & $\begin{array}{c}\text { This study } \\
\text { This study } \\
\text { Ohayon and Stepien, } 2007\end{array}$ \\
\hline $\begin{array}{l}\text { Strwiąż } \\
\text { Krościenko (STR1) }\end{array}$ & VI-X 2013 & $\begin{array}{l}43 \\
43\end{array}$ & $\mathrm{~A}(0.98), \mathrm{E}(0.02)$ & This study \\
\hline $\begin{array}{l}\text { Dniester } \\
\text { Makarovka and Yampil (4) } \\
\text { Belgorod Dnestrovsky } \\
\text { and Bilyayivka (5) }\end{array}$ & 2006 & $\begin{array}{c}46 \\
9\end{array}$ & $\begin{array}{c}\mathrm{A}(0.78), \mathrm{B}(0.11), \mathrm{E}(0.11) \\
\mathrm{A}(0.86), \mathrm{F}(0.14)\end{array}$ & $\begin{array}{l}\text { Ohayon and Stepien, } 2007 \\
\text { Ohayon and Stepien, } 2007\end{array}$ \\
\hline $\begin{array}{l}\text { Dnieper } \\
\text { Kiev (7) } \\
\text { Zaporizhzhya Reservoir (8) }\end{array}$ & $\begin{array}{l}2006 \\
2006\end{array}$ & $\begin{array}{c}12 \\
10 \\
2\end{array}$ & $\begin{array}{l}\mathrm{G}(0.80), \mathrm{H}(0.20) \\
\mathrm{G}(0.50), \mathrm{H}(0.50)\end{array}$ & $\begin{array}{l}\text { Ohayon and Stepien, } 2007 \\
\text { Ohayon and Stepien, } 2007\end{array}$ \\
\hline
\end{tabular}


Tab. 2. Pair-wise population $\mathrm{F}_{\mathrm{st}}$ analog (Weir and Cockerham, 1984) (below diagonal) and $\chi^{2}$ contingency test comparisons (Raymond and Rousset, 1995) (above diagonal) among population samples of the racer goby (Babka gymnotrachelus), using Arlequin 3.5.1.3 (Excoffier and Lischer, 2010). Numbers beside locations correspond to sampling sites of Tab.1 and Fig. 1.

\begin{tabular}{|c|c|c|c|c|c|}
\hline \multicolumn{6}{|c|}{ Vistula-Western Bug vs Dnieper } \\
\hline & Western Bug (S3) & Western Bug (S9) & Vistula (S11) & Vistula (S15) & Middle Dnieper \\
\hline Western Bug (S3) & - & - & - & - & * \\
\hline Western Bug (S9) & -0.12 & - & - & - & * \\
\hline Vistula (S11) & -0.11 & -0.11 & - & - & * \\
\hline Vistula (S15) & -0.05 & -0.05 & -0.06 & - & * \\
\hline Middle Dnieper (7) & $0.60 *$ & $0.60 *$ & $0.64 *$ & $0.73 *$ & - \\
\hline \multicolumn{6}{|c|}{ Strwiąż us Dniester } \\
\hline & Strwiąż (STR) & Middle Dniester (4) & Dniester Estuary (5) & & \\
\hline Strwiąż (STR) & - & - & $*$ & & \\
\hline Middle Dniester (4) & 0.10 & - & * & & \\
\hline Dniester Estuary (5) & $0.10 *$ & 0.00 & - & & \\
\hline
\end{tabular}

*Significantly different at $P=0.05$.
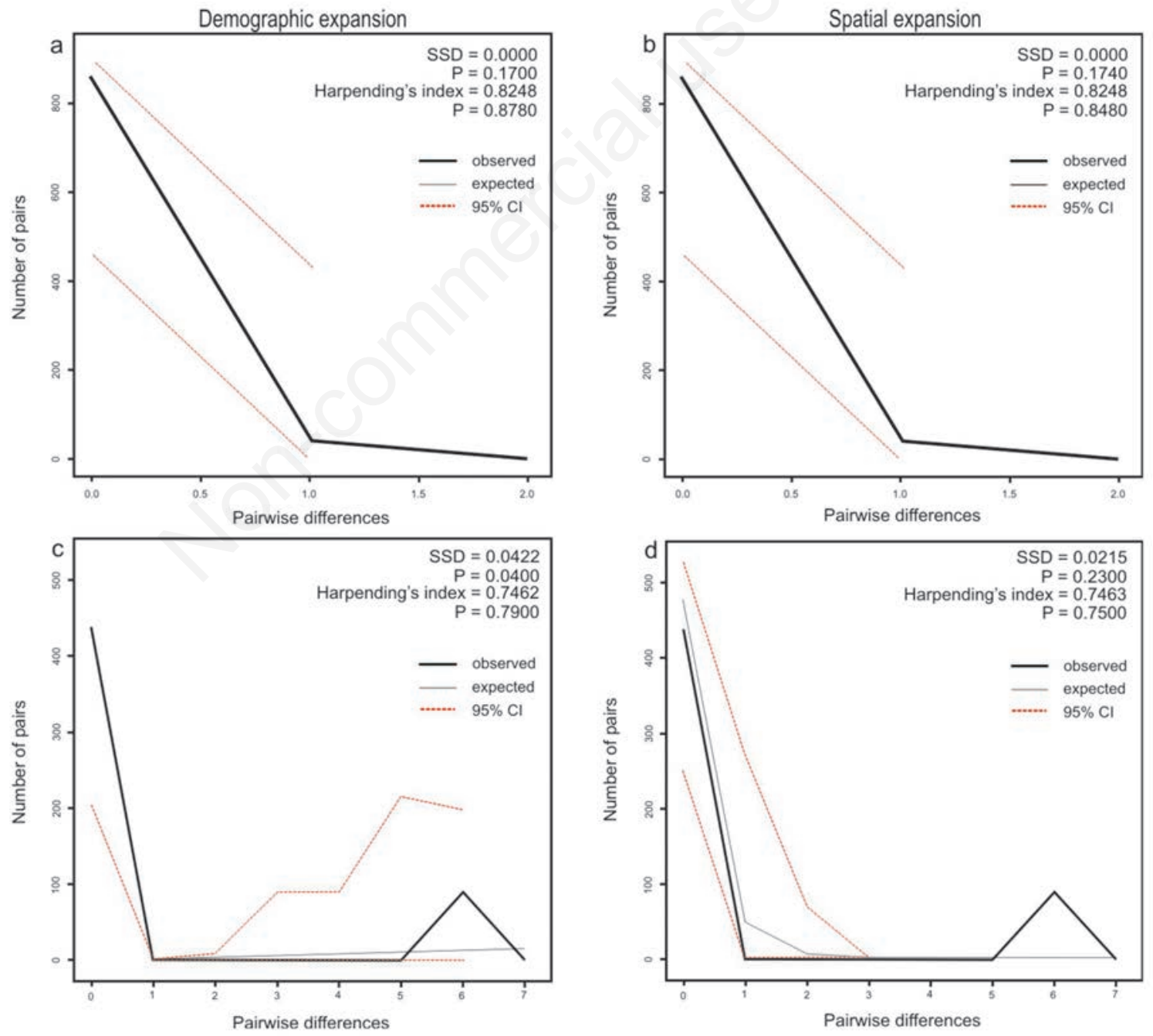

Fig. 2. Mismatch distribution analysis, under demographic and spatial expansion models, of the racer goby (Babka gymnotrachelus) populations from the newly colonised rivers. a,b) Strwiąż River. c,d) Vistula and Western Bug Rivers. 
of long distance transport of limited number of individuals from the Dnieper. However, the obtained picture may also result from a rather limited sample size, obtained by Ohayon and Stepien (2007) from the Dnieper River. Thus any interpretation must be treated with caution.

The genetic composition of racer goby population in the Strwiąż River has not been studied so far. Our results show that the haplotype assemblage found in Strwiąz is a subsample of assemblages identified by Ohayon and Stepien (2007) in the Dniester River. Taking into account lack of differentiation between the north-western Dniester and Strwiąż populations as well as the signs of spatial and demographic expansion in the latter, the Dniester River can be authenticated as a source from which the Strwiąż populations originated. A question remains whether the population of racer goby in the Strwiąż River is a native element of fish fauna, like in the others tributaries of the Dniester (Smirnov, 1986; Khudyi, 2002; Romanescu, 2010; Manilo, 2014) or an alien that arrived there recently due to human-mediated range expansion.

The earliest reports of the racer goby from Dniester come from the $19^{\text {th }}$ century and the species was actually described by Kessler (1857) from the Zbruch River that is a Dniester tributary. The historical information on the distribution of racer goby in the upper Dniester, to which Strwiąż empties, is rather obscure without exact locality data. According to literature the species was generally common and abundant in the upper Dniester in the 1940s (e.g., Jaroshenko et al., 1951; Tatarinov, 1988). Khudyi (2002) reported that in 1960s the species was found in Dniester at least up to the Bystrica mouth, ca. $154 \mathrm{~km}$ downstream from the Strwiąż mouth. Unfortunately, despite much effort paid we could not find any surveys upon the ichthyofauna of the more upper stretch of Dniester. It must be noted that also the fish fauna in the Ukrainian part of the Strwiąż River has never been surveyed. The racer goby was not found in the Polish part of Strwiąż in 1960s, however it must be noted that this historical study included only the uppermost, mountain, section of the river (Rolik, 1967, 1971). That section is characterised by stony/pebble bottom with scarcity of gravel-sandy patches and high water velocity $0.35-0.62 \mathrm{~m} \mathrm{~s}^{-1}$ during middle discharges (Kukuła and Bylak, unpublished data). Also, no racer goby was found during more recent surveys of same sites in 2003 and 2009 (Amirowicz and Kukuła, 2005; Kukuła and Bylak, 2010). On the other hand, these latter surveys revealed abundant presence of the species, including all age groups, in more downstream section of Strwiąż, with gravel/stony bottom and sand alluvia with mud layer along the banks. Water velocity was much lower there $\left(0.22-0.36 \mathrm{~m} \mathrm{~s}^{-1}\right)$ to almost stagnant conditions in some parts of the river bed. Racer goby occurred mainly along the banks where velocity ranged from 0.02 to 0.12 $\mathrm{m} \mathrm{s}^{-1}$ (Kukuła and Bylak, unpublished data). Kakareko et al. (2014) revealed that in rivers racer goby occurs mainly in habitats outside the main channel, with relatively slow water velocities on both soft and hard bottom, using a variety of submerged objects as shelters. Also laboratory experiments showed that preferable habitat of racer gobies, irrespective of their size, includes slow water current of ca. $0.1 \mathrm{~m} \mathrm{~s}^{-1}$ and muddy bottom (Kakareko, 2011). Thus we may suppose that absence of racer goby in Strwiąż in the historical study by Rolik $(1967,1971)$ could result from sampling in the river section with environmental conditions avoided by the species. For example, Polačik et al. (2008) and Haertl et al. (2012) pointed out that infrequent findings of racer goby in Danube are probably due to the fact that most surveys focus on main channel of the river avoided by the racer goby, which is abundant in more muddy and stagnant waters along the river banks. Thus, quite possibly the racer goby is not a newcomer in Strwiąż but simply was overlooked in the only earlier study upon ichthyofauna of this river.

An alternative explanation would be a recent arrival of the species via spontaneous range or human-mediated expansion. However, there is no evidence for such scenarios. For example human-mediated passive dispersal with ships and barges can be excluded, as there is no such traffic along the upper Dniester and Strwiąż. The supporting role of artificial dam reservoirs in the species upstream expansion, often mentioned in case of the invasive goby species in large rivers of Ponto-Caspian basin (Slynko et al., 2011), can be rejected as racer goby was present in the upper Dniester long before the construction of such reservoirs on this river (Khudyi, 2002). Transport by anglers could be taken into account, however: i) there is no cross-border movement of anglers with live bait between Poland and Ukraine; ii) the results of tests for population differentiation between middle Dniester and Strwiąż do not suggest point-introductions of low number of individuals (possible founder effect). Finally, due to the lack of historical data from Ukraine upon the distribution of racer goby, we can neither assume nor exclude a recent natural expansion of the species. Generally, according to the rule innocent until proven guilty, the racer goby in Strwiąż cannot be treated as an alien invasive species, contrary to its status in the Vistula drainage. A number of definitions have been proposed for the term alien species (Copp et al., 2005), but generally they underline the human factor. For example IUCN (2000) defines alien species as species, subspecies, or lower taxon occurring outside of its natural range (past or present) and dispersal potential (i.e., outside the range it occupies naturally or could not occupy without direct or indirect introduction or care by humans). This definition was adopted by The European Parliament and the Council of European Union as a party to the Convention on Biological Diversity and used in their regulations considering invasive species policy in 
Europe. On the other side, the EU regulation on alien species, No $1143 / 2014$, specifies that species that migrate naturally, e.g., in response to environmental changes, should not be considered as alien in their new environment and should be excluded from the scope of this regulation. Obviously in many instances it is hard to differentiate and highly speculative whether, and to what extent, the environmental changes are natural or humanmediated, especially in indirect way. In cases when a species is not demonstrably native to particular areas, neither evidently introduced, Carlton (1996) proposed the term cryptogenic. In our opinion, the racer goby was most probably overlooked in the historical survey on the ichthyofauna in the Strwiąż River. Thus, its population in this river should probably be treated as native. Alternatively and most cautiously, to leave some window of uncertainty, we could treat it as cryptogenic. By no means, whatsoever, we have an evidence to treat it as alien.

\section{CONCLUSIONS}

This double origin of racer goby populations in Poland creates a peculiar situation for the national legislation procedures as one population of a species is clearly alien and invasive, while the other one is not. According to the Polish legislation acts, the racer goby has been enlisted as an alien invasive species whose release to the environment is forbidden due to the possible threat it may pose to local biota (Rozporządzenie Ministra, 2011). In light of our findings, the population from Strwiąż should be recognised as a special case and excluded from that list. Furthermore, some steps should be undertaken to raise public awareness to prevent translocation of the gobies between the rivers to prevent deterioration of the evolutionarily isolated genetic pools of the Dnieper and of the Dniester basins.

Our results illustrate the need for case studies upon genetic population structure, following appearance of new species in previously unoccupied water bodies, even on local scale. Such studies are often neglected yet they may bring interesting results, important for conservational purposes.

\section{ACKNOWLEDGMENTS}

We would like to thank dr Yuliya Kutsokon from the National Taras Shevchenko University of Kyiv and dr Oleksii Khudyi from Chernivtsi National University, in Ukraine, for their help in revision of historical literature concerning racer goby distribution in the Dniester River. Samples from the Western Bug and Vistula were collected during fieldwork supported by the grant NN 304409239 from the Ministry of Sciences and Higher Education of Poland. We would like to thank Mykola Ovcharenko, Katarzyna Mierzejewska and Yuriy Kvach for their assistance in sampling.

\section{REFERENCES}

Amirowicz A, Kukuła K, 2005. Stream habitat conditions and fish fauna within the occurrence range of Wałecki barbel, Barbus cyclolepis waleckii Rolik, 1970 (Teleostei: Cyprinidae) in Polish part of the Carpathian Mts. Pol. J. Ecol. 53:503-522.

Akihito IA, Kobayashi T, Ikeo K, Imanishi T, Ono H, Umehara Y, Hamamatsu C, Sugiyama K, Ikeda Y, Sakamoto K, Fumihito A, Ohno S, Gojobori T, 2000. Evolutionary aspects of gobioid fishes based upon a phylogenetic analysis of mitochondrial cytochrome $b$ genes. Gene 259:5-15.

Bij de Vaate A, Jażdżewski K, Ketelaars H, Gollasch S, Van der Velde G, 2002. Geografical patterns in range expantion of macroinvertebrate Ponto-Caspian species in Europe. Can. J. Fish. Aquat. Sci. 59:1159-1174.

Borcherding J, Gertzen S, Staas S, 2011. First record of Pontian racer goby, Babka gymnotrachelus (Gobiidae: Teleostei), in the River Rhine, Germany. J. Appl. Ichthyol. 27:1399-1400.

Copp GH, Bianco PG, Bogutskaya NG, Erös T, Falka I, Ferreira MT, Fox MG, Freyhof J, Gozlan RE, Grabowska J, Kováč V, Moreno-Amich R, Naseka AM, Peňáz M, Povž M, Przybylski M, Robillard M, Russell IC, Stakenas S, Šumer S, Vila-Gispert A, Wiesner C, 2005. To be, or not to be, a nonnative freshwater fish? J. Appl. Ichthyol. 21:242-262.

Danilkiewicz Z, 1996. [Racer goby, Neogobius gymnotrachelus (Kessler, 1857), Perciformes, Gobiidae - a new species in the Baltic Sea basin].[Article in Polish]. Komunikaty Rybackie 2:27-29.

Excoffier L, Lischer HEL, 2010. Arlequin suite ver 3.5: a new series of programs to perform population genetics analyses under Linux and Windows. Mol. Ecol. Resour. 10:564-567.

Grabowska J, Pietraszewski D, Ondračková M, 2008. Tubenose goby Proterorhinus marmoratus (Pallas, 1814) has joined three other Ponto-Caspian gobies in the Vistula River (Poland). Aquat. Invasions 3:261-265.

Grabowska J, Witkowski A, Kotusz J, 2010. Alien invasive fish species in Polish waters: an overview. Folia Zool. 59:73-85.

Haertl M, Cerwenka AF, Brandner J, Borcherding J, Geist J, Schliewen U, 2012. First record of Babka gymnotrachelus (Kessler, 1857) from Germany (Teleostei, Gobiidae, Benthophilinae). Spixiana 35:155-159.

Hall, TA, 1999. BioEdit: a user-friendly biological sequence alignment editor and analysis program for Windows 95/98/NT. Nucleic Acids Symp. Ser. 41:95-98.

Hillis DM, Moritz C, Mable BK, 1996. Molecular systematics, $2^{\text {nd }}$ ed. Sinauer Associates Inc, Sunderland: $655 \mathrm{pp}$.

IUCN, 2000. IUCN Guidelines for the prevention of biodiversity loss caused by alien invasive species. Available from: https://portals.iucn.org/library/efiles/documents/Rep-2000051.pdf

Jaroshenko MF, Ganja IM, Val'kovskaja OI, Naberezhnyj AI, 1951. [On the ecology and economic importance of some fish species in the Dniester River].[Article in Russian]. Izvestija Mold. Fil. Akad. Nauk SSSR 1:273-294.

Kakareko T, 2011. [Impact of selected factors on the distribution and habitat preferences of two non-native fish species in Poland - racer goby (Neogobius gymnotrachelus Kessler, 1857) and monkey goby (Neogobius fluviatilis Pallas, 1811)].[PhD Thesis in Polish with English abstract]. University Mikolaja Kopernika. 
Kakareko T, Kobak J, Poznańska M, Jermacz Ł, Copp GH, 2014. Underwater evaluation of habitat partitioning in a European river between a non-native invader, the racer goby and a threatened native fish, the European bullhead. Ecol. Freshw. Fish DOI: 10.1111/eff.12191.

Khudyi OI, 2002. [Changes in fish fauna at different sections of the Dniester River under influence of antropogenous factors].[Article in Russian]. Gidrobiologiceskij Zurnal 38:33-39.

Kostrzewa J, Grabowski M, 2001. [Racer (goad) goby Neogobius gymnotrachelus (Kessler, 1857) (Gobiidae, Perciformes) - a new fish species in the Vistula River].[Article in Polish with English abstract]. Przegląd Zoologiczny 45:101-102.

Kostrzewa J, Grabowski M, 2003. Opportunistic feeding strategy as factor promoting the expansion of racer goby (Neogobius gymnotrachelus Kessler, 1857) in the Vistula basin. Lauterbornia 48:91-100.

Kukuła K, Bylak A, 2010. [Ichthyofauna of upper Strwiąż and Mszanka rivers].[Article in Polish]. Roczniki Bieszczadzkie 18:178-191.

Kukuła K, Bylak A, 2013. [The native population of racer goby Neogobius gymnotrachelus in Poland?].[Article in Polish]. Chrońmy Przyrodę Ojczystą 69:61-65.

Manilo LG, 2014. [Gobiids (Perciformes, Gobiidae) of marine and brackish waters of Ukraine].[Book in Russian]. Naukowa Dumka, Kiev: 243 pp.

Ohayon JL, Stepien CA, 2007. Genetic and biogeographic relationships of the racer goby Neogobius gymnotrachelus (Gobiidae: Teleostei) from introduced and native Eurasian locations. J. Fish. Biol. 71:360-370.

Panov VE, Alexandrov BG, Arbaciauskas K, Binimelis R, Copp GH, Grabowski M, Lucy F, Leuven RS, Nehring S, Paunović M, Semenchenko V, Son MO, 2009. Assessing the risks of aquatic species invasions via European inland waterways: from concepts to environmental indicators. Integr. Environ. Assess. Manag. 5:110-126.

Polačik M, Janáč M, Trichkova T, Vassilev M, Keckeis H, Jurajda P, 2008. The distribution and abundance of Neogobius fishes in their native range (Bulgaria) with notes on the nonnative range in the Danube River. Large Rivers 18:193-208.

Raymond M, Rousset F, 1995. An exact test for population differentiation. Evolution 49:1280-1283.

Roche KF, Janáč M, Jurajda P, 2013. A review of Gobiid expansion along the Danube-Rhine corridor - geopolitical change as a driver for invasion. Knowl. Manag. Aquat. Ec. 411:01.
Rogers AR, Harpending H, 1992. Population growth makes waves in the distribution of pairwise genetic differences. Mol. Biol. Evol. 9:552-569.

Rolik H, 1967. [Contributions to the ichthyofauna of Strwiąż (a tributary of Dniestr) with special reference to Gobio gobio (L.) and Cobitis (Sabanejewia) aurata (Fil.)].[Article in Polish]. Fragm. Faun. 14:133-151.

Rolik H, 1971. [Studies on three Barbus species (Pisces, Cyprinidae, Cuvier 1817) in San and Wisłoka basins].[Article in Polish]. Annales Zoologici 28:257-330.

Romanescu VC, 2010. [Distribution of the goby fishes (Perciformes: Gobiidae) in the Prut-Dniester hydrographic interfluvial space, p. 168-191].[Article in Russian]. Proceedings Int. Conf. Dniester River basin: ecological problems and the management of transboundary natural resources, Tiraspol, Transnistria.

Rozporządzenie Ministra, 2011. [Regulation of the Minister of the Environment of 9 September 2011 on the list of plants and animals alien species that can threaten native species and natural habitats if released into the environment]. [in Polish]. Official Journal no. 210 - 1260.

Semenchenko V, Grabowska J, Grabowski M, Rizevsky V, Pluta M, 2011. Non-native fish in Belarusian and Polish areas of the European central invasion corridor. Oceanol. Hydrobiol. Stud. 40:1-11.

Seutin G, White BN, Boag PT, 1991. Preservation of avian blood and tissue samples for DNA analysis. Can. J. Zool. 69:82-90.

Slatkin M, Hudson RR, 1991. Pairwise comparisons of mitochondrial DNA sequences in stable and exponentially growing populations. Genetics 129:555-562.

Slynko YV, Dgebuadze YY, Novitskiy RA, Kchristov OA, 2011. Invasions of Alien Fishes in the Basins of the Largest Rivers of the Ponto_Caspian Basin: Composition, Vectors, Invasion Routes, and Rates. Russ. J. Biol. Invasions 2:49-59.

Smirnov AI, 1986. [Perciformes (Gobioidei), Scorpaeniformes, Pleuronectiformes, Gobiesociformes, Lophiiformes].[Book in Russian]. Series Fauna of Ukraine 8, Fish (5). Naukova Dumka, Kiev: 320 pp.

Tatarinov KA, 1988. [Fish, p. 160-161]. In: M.A. Holubets, M.T. Honchar, V.I. Komendar, V.A. Kucheryavyi and Y.P. Odynak (eds.), [The nature of the Ukrainian Carpathians]. [Book in Russian]. Naukova Dumka, Kiev.

Weir BS, Cockerham CC, 1984. Estimating F-statistics for the analysis of population structure. Evolution 38: 1358-1370. 